Rev.MVZ Córdoba 20(3):4807-4814, 2015. ISSN: 0122-0268

SHORT COMMUNICATION

\title{
Curve control, development and phenotypic bad formations in poodle the city of Medellin
}

\section{Curva de control, desarrollo y mal formaciones fenotípicas en Poodle en la ciudad de Medellín}

\author{
José Ortiz Á, Esp. \\ Corporación Universitaria Lasallista, Centro Veterinario Génesis. Carrera 51 №118Sur - 57. Caldas - \\ Antioquía *Correspondencia: cvgenesis1@yahoo.com.ar
}

Received: October 2014; Accepted: February 2015.

\begin{abstract}
Objective. Quantifying phenotypic malformations and make a curve control and development of the breed Poodle puppies in the city of Medellin. Materials and methods. We analyzed 60 individuals, 30 females and 30 males were measured and weighed from 2 to 12 months of age with these data, build a table and a control growth curve and after about 12 months of age there were the Phenotypic malformations, which are considered by the American Kennel Club (AKC) and Cynological International (FCI). Results. Of the specimens analyzed, $10 \%$ had bone spurs, cryptorchidism $20 \%$, $5 \%$ had polidoncia a year old, with teeth retained teeth more often. Conclusions. In an effort to find examples of smaller faults have been committed at the time of mating, resulting in increased phenotypic malformations found in the study, this work also provide veterinarians, another tool for assessing pediatric puppies Poodle race in the city of Medellin.
\end{abstract}

Key words: Canines, height, malformations phenotype, weight (Source:CAB).

\section{RESUMEN}

Objetivo. Cuantificar las malformaciones fenotípicas y realizar una curva de control y desarrollo, de cachorros de la raza Poodle en la ciudad de Medellín. Materiales y métodos. Se analizaron 60 individuos; 30 hembras y 30 machos, se midieron y se pesaron desde los 2 hasta los 12 meses de edad; con estos datos se construyó una tabla y una curva de control del crecimiento; a los 12 meses de edad se contabilizaron las malformaciones fenotípicas, las cuales son consideradas por la American Kennel Club (AKC) y la Federación Cinologica Internacional (F.C.I). Resultados. De los ejemplares analizados, un $10 \%$ tenían espolones, $20 \%$ criptorquidismo y $5 \%$ presentaban polidoncia al año de edad, siendo los colmillos los dientes retenidos con más frecuencia. Conclusiones. Por el afán de encontrar ejemplares de menor tamaño se han cometidos fallas al momento de realizar los apareamientos, dando como resultado el aumento de las malformaciones fenotípicas encontradas en el estudio, con este trabajo también se ofrecer a los veterinarios, otra herramienta más para la evaluación pediátrica de los cachorros de la raza Poodle en la ciudad de Medellín.

Palabras clave: Caninos, fenotipo, malformaciones, peso, talla (Fuente: $C A B$ ). 


\section{INTRODUCTION}

All live beings fulfill a series of stages such as to be born, to grow, to reproduce and to die; growth and development are fundamental stages that form some characteristics that helps to move on to other stages $(1,2)$.

In human medicine, the terms growth and development are an interdisciplinary area that involves all activities for a child to have a physical and intellectual development similar in comparison with their peers. This is accomplished with the implementation of measurement tables and growth curves (1).

In veterinary medicine, this subject is not widely studied. Some growth tables exist for bovine, equine and canine animal breeding to ensure a good phenotypic and production development $(3,4)$.

The American Kennel Club (AKC) categorizes the poodle within group 5 or companion or toy dogs; the World Canine Organization (F.C.I.) categorizes the poodle ingroup IX section 2 poodles $(5,6)$.

The guidelines given by these associations are directed to the conservation of some standards for some dog breeds, whether these are for exhibition or companion dogs $(6,7)$.

These associations consider several factors such as weight, size, coat color and body characteristics to form a standard for each breed. They also dictate failures or penalties that a particular specimen deserves $(6,8)$.

In the city of Medellin, one of the most popular canine breeds is the poodle. Because of this and because of the breeder's eagerness to achieve a small size specimen (the so called tea cup), a degeneration of the characteristics of this breed has occurred.

With the problem in mind and because of the lack of tools to adequately measure the development of the puppies from this breed, a work was conducted in which 60 poodle puppies were subjected to analysis of different variables such as weight, size, coat color and they were compared to the international standard; also, a table and growth and development control cure was developed in order to assess the progress of these puppies. This analysis could be another tool for analysis by small animal clinics for a better pediatric assessment of this specimen.

\section{INTRODUCCIÓN}

Todos los seres vivos cumplen una serie de etapas como son nacer, crecer, reproducirse y morir; el crecimiento y desarrollo es una etapa fundamental que permite formar unas características que ayudan a superar las otras etapas $(1,2)$.

En medicina humana, el termino crecimiento y desarrollo es un área interdisciplinaria que involucra todas las actividades concernientes a que un niño tenga un desarrollo físico e intelectual similar en comparación con sus congéneres de su misma edad, esto se logra con la implementación de tablas de medidas y curvas de crecimiento (1).

En medicina veterinaria este tema no tiene amplia difusión, solo existen algunas tablas de crecimiento para la crianza de ganado vacuno, equino y canino para procurar un buen desarrollo fenotípico y de producción $(3,4)$.

La American Kennel Club (AKC) categoriza al caniche ó poodle dentro del grupo 5 ó perros de juguete ó compañía, la Federación Cinologica Internacional (F.C.I) lo categoriza en el grupo IX sección 2 caniches $(5,6)$.

Los lineamientos que dan estas asociaciones se dirigen a conservar unos estándares para las razas de perros, sean estos de exposición ó como perros de compañía $(6,7)$.

Estas asociaciones tienen en cuenta varios factores como el peso, la talla, el color del manto y las características del cuerpo para conformar el estándar de cada raza, también dictaminan las faltas ó penalizaciones que merezca un ejemplar $(6,8)$.

En la ciudad de Medellín una de las razas caninas más popular es el caniche o poodle, fruto de esto y con el afán de los criadores de conseguir un ejemplar de tamaño pequeño (mal llamada tacita de te) se ha producido una degeneración en las características de esta raza.

Viendo el problema y por la falta de herramientas para medirse adecuadamente el desarrollo de los cachorros de esta raza, se realizó un trabajo en el cual a 60 cachorros poodle, se les analizó diferentes variables como el peso, la talla, el color del manto y se compararon con el estándar internacional, además se realizó una tabla y una curva de control del crecimiento y desarrollo, para poder evaluar el progreso de los cachorros y que esta se ha otra herramienta de análisis utilizada por los clínicos de pequeños animales para una mejor evaluación pediátrica de estos ejemplares. 


\section{MATERIALS AND METHODS}

Study location. The data used was obtained from the Genetic Veterinary Center in the city of Medellin (Colombia).

Selection of specimens. The only factor that was considered to select the specimens was that these were sons of phenotypically recognized poodle dogs or that they would come from a kennel.

Type of study. A descriptive study was conducted in which 60 puppies of the poodle breed ( 30 male and 30 female) from 2 to 12 months old were monitored.

Weight, measurement and record of phenotypical malformations. Each specimen was measured from the floor to the cross (Figure 1 ). They were measured in a scale and at the last visit, the length was measured from the occiput to the tail, the body condition, the color coat and also the phenotypical malformations found were recorded.

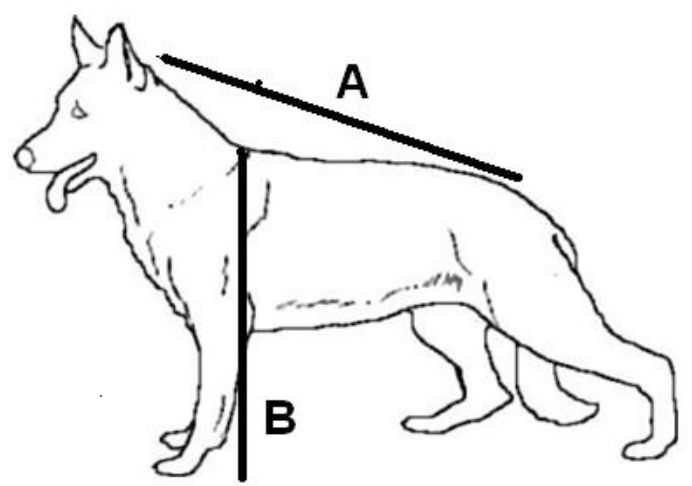

Figure 1. Measurement method used, line $A$ from the base of the tail to the occiput, line $B$ from the cross to the floor (own design image).

Statistical analysis. The data is described with a percentile for phenotypical malformations and the average; percentiles 25, 50 and 75 of weight and size to build the curves and the body condition was measured in a scale of 1 to 5 (9); Excel Microsoft Office ${ }^{\circledR} 2007$ was used to determine the previous values.

\section{RESULTS}

With respect to the color of the coat it was found that 43 specimen were white, which is equivalent to $71.6 \%$ of the total; 6 were black $(10 \%)$ and

\section{MATERIALES Y MÉTODOS}

Sitio de estudio. Los datos utilizados fueron obtenidos del Centro Veterinario Génesis, ubicado en la ciudad de Medellín (Colombia).

Sección de los ejemplares. El único factor que fue tenido en cuenta para escoger los ejemplares fue que estos fueran hijos de perros poodle reconocidos fenotípicamente o que provinieran de algún criadero.

Tipo de estudio. Se realizó un estudio descriptivo, donde se efectuó el seguimiento a 60 cachorros de la raza poodle (30 machos y 30 hembras) desde los 2 hasta los 12 meses de edad.

Pesaje, medición y registro de malformaciones fenotípicas. Se midió cada ejemplar desde el piso hasta la altura de la cruz (Figura 1), se pesaron en una bascula y en la última visita se midió el largo desde el occipucio hasta la base de la cola, la condición corporal, el color del manto y se registraron las malformaciones fenotípicas encontradas en este momento.

Análisis estadístico. Los datos se describen mediante la obtención del porcentaje para las mal formaciones fenotípicas y el promedio, percentiles 25,50 y 75 del peso y de la talla, para construir las curvas y la condición corporal medida en una escala de 1-5 (9); se utilizó el programa Microsoft Office Excel ${ }^{\circledR} 2007$ para la determinación de los valores anteriores.

\section{RESULTADOS}

En cuanto al color del manto se encontró que 43 ejemplares eran blancos lo que equivalía a un $71.6 \%$ del total, 6 eran negros $(10 \%)$ y $11(18.5 \%)$ eran de otro color en los que se encuentra grises, albaricoque y combinaciones de colores.

En cuanto a otros hallazgos se encontró que 6 ejemplares que corresponden a un $10 \%$, presentaban espolones, 6 machos que correspondían a un $20 \%$ eran criptorquidos, 3 individuos que equivalían a un $5 \%$ presentaban polidoncia al año de edad siendo los colmillos los dientes retenidos más frecuentes, 1 hembra $(1.6 \%)$ presento al año de edad prognatismo inferior, también se pudo observa al año de edad que solo 3 hembras que equivalía a un $10 \%$ habían sido esterilizadas y ningún macho había sido esterilizado y por último a 3 ejemplares que equivalen a un $3.3 \%$ por decisión de sus dueños 
$11(18.5 \%)$ were of another color, among which are grays, apricot and a combination of colors.

With respect to other findings, it was found that 6 specimens that correspond to $10 \%$ presented bone spurs; 6 male, which correspond to $20 \%$, had cryptorchidism; 3 individuals, which correspond to $5 \%$, presented polydontia at age one, being the tusk of the retained tooth the most frequent; 1 female (1.6\%) presented lower prognathism by age one; also, by age one, it was observed that only 3 females, equivalent to $10 \%$, had been sterilized and no male had been sterilized; lastly, 3 specimens equivalent to $3.3 \%$, had not been subjected to caudectomy because their owners consider this practice to be aberrant.

With respect to the size, it was found that 38 specimen, equivalent to $63.3 \%$, were categorized as miniature and 22 specimen (36.6\%) were categorized as minitoy.

With respect to the body condition measured between 1-5, it was found that at age one, from the total, 22 specimen showed a body condition of less than 3; of these, 9 were male, corresponding to $40.9 \%$ and 13 were female $(59 \%) ; 29$ had a body condition of 3 ; from these, $8(27.5 \%)$ were male and $21(72.4 \%)$ were female; 9 animals had a body condition greater than 3, $6(66.6 \%)$ were male and $3(33.3 \%)$ were female.

With the sizes and weights recollected, the following tables were elaborated for male and for female, which have the 25, 50 and 75 percentiles; also, with these values, a growth curve was build for each gender (Tables 1, 2 and Figures 2-5).

Table 1. Size and weight of females of the Poodle breed 2 to 12 months old size percentiles $(\mathrm{cm})$, weight percentiles $(\mathrm{kg})$.

\begin{tabular}{ccccccc}
\hline Weight (kg) & \multicolumn{7}{c}{ Age (months) } \\
\hline Percentiles & 2 & 4 & 6 & 8 & 10 & 12 \\
25 & 1.0 & 1.5 & 2.0 & 2.6 & 2.7 & 3.0 \\
50 & 1.0 & 2.1 & 3.0 & 3.4 & 3.4 & 4.0 \\
75 & 2.0 & 2.5 & 3.2. & 4.0 & 4.3. & 4.8 \\
Size (cm) & & & & & & \\
25 & 14 & 16 & 18.6 & 22 & 23 & 24 \\
50 & 15 & 17.5 & 21 & 24.5 & 26.5 & 27 \\
75 & 16 & 19 & 24.8 & 27.8 & 29.6 & 30 \\
\hline
\end{tabular}

al considerar una práctica aberrante no se les había realizado caudectomia

En cuanto al tamaño se encontró que 38 ejemplares que equivalen a un $63.3 \%$ se categorizaron como miniatura y 22 ejemplares $(36.6 \%)$ se categorizaron como minitoy.

En cuanto a la condición corporal medida de $1-5$, se encontró lo siguiente al año de edad, del total, 22 ejemplares presentaron condición corporal menor a 3, de estos 9 eran machos que correspondían a un $40.9 \%$ y 13 eran hembras (59\%); 29 tenían condición corporal de 3; de estos $8(27.5 \%)$ eran machos y $21(72.4 \%)$ eran hembras; con condición corporal mayor a 3 se encontró 9 animales, $6(66.6 \%)$ eran machos y $3(33.3 \%)$ eran hembras.

Con las tallas y pesos recolectados se conformaron las siguientes tablas para machos y para hembras las cuales contienen los percentiles 25,50 y 75, además con estos valores se construyo una curva de crecimiento para cada género (Tablas 1,2 y Figuras 2-5).

\section{DISCUSIÓN}

Desde el momento mismo de la concepción, todo ser vivo adquiere una determinación genética que repercutirá durante toda su vida, pero inmediatamente empieza a ser influenciada por el medio ambiente en su proceso de crecimiento y desarrollo $(1,10)$.

A lo anterior hay que sumarle la nutrición, todas las razas de perros tienen unos requerimientos nutricionales, los cuales van a depender del tamaño

Table 2. Size and weight of males of the Poodle breed 2 to 12 months old.

\begin{tabular}{ccccccc}
\hline Weight $(\mathbf{k g})$ & \multicolumn{7}{c}{ Age (months) } \\
\hline Percentiles & 2 & 4 & 6 & 8 & 10 & 12 \\
25 & 1.0 & 2.0 & 2.7 & 3.0 & 3.2. & 3 \\
50 & 1.7 & 2.5 & 3.0 & 4.0 & 4.3. & 4.0 \\
75 & 2.0 & 3.0 & 3.5 & 4.4 & 5.3. & 5.0 \\
Size (cm) & & & & & & \\
25 & 15 & 17.3. & 20 & 22 & 24 & 25 \\
50 & 15 & 19 & 22 & 24 & 26.5 & 27 \\
75 & 17 & 22 & 24 & 26 & 29.6 & 30 \\
\hline
\end{tabular}




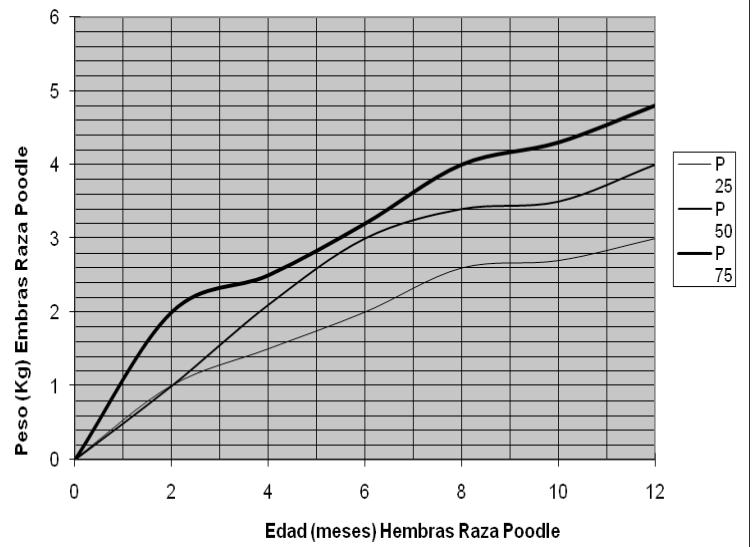

Figure 2. Curve of percentiles 25, 50, 75 of the weight in kilograms of females from the poodle breed 2 to 12 months old.

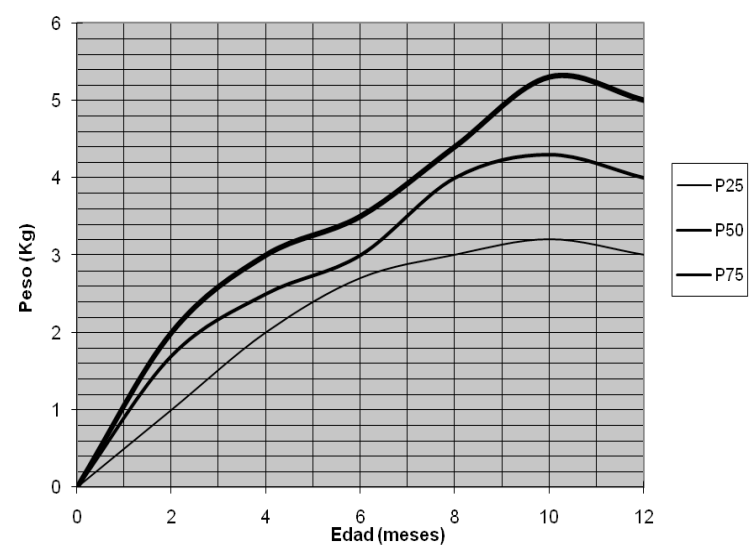

Figure 4. Curve of percentiles 25, 50, 75 of the weight in kilograms of males from the Poodle breed 2 to 12 months old.

\section{DISCUSSION}

From the moment of conception, all live beings acquire a genetic determination that will have an impact during their entire life, but that immediately starts to become influenced by the environment in its growth and development process $(1,10)$.

Nutrition must also be added to this; all dog breeds have nutritional requirements that will depend on the size of the specimen, the sex and the activity (11). When observing the results obtained in this study, we found that the white coat color prevails over the other colors. Among the owners of poodle dogs in our environment, there is a belief that white color specimens are more pure than other color specimens. This is due to lack of information on breed standards $(6,7)$

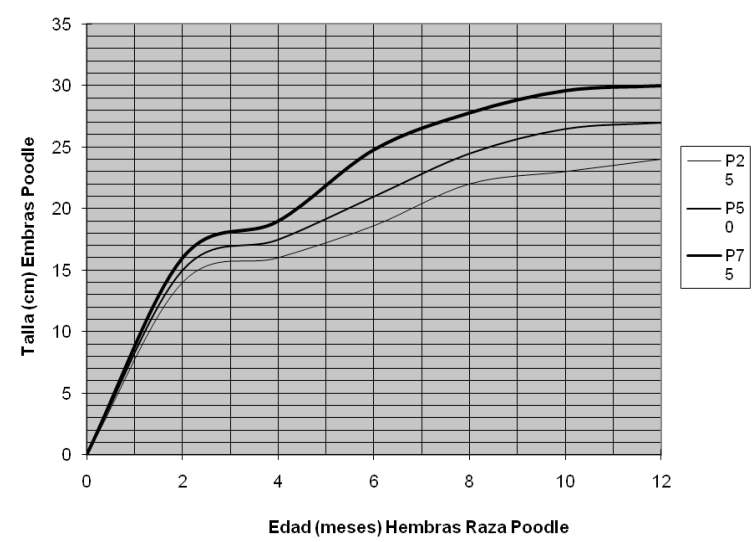

Figure 3. Curve of percentiles 25, 50, 75 of the size in centimeters of females from the Poodle breed 2 to 12 months old.

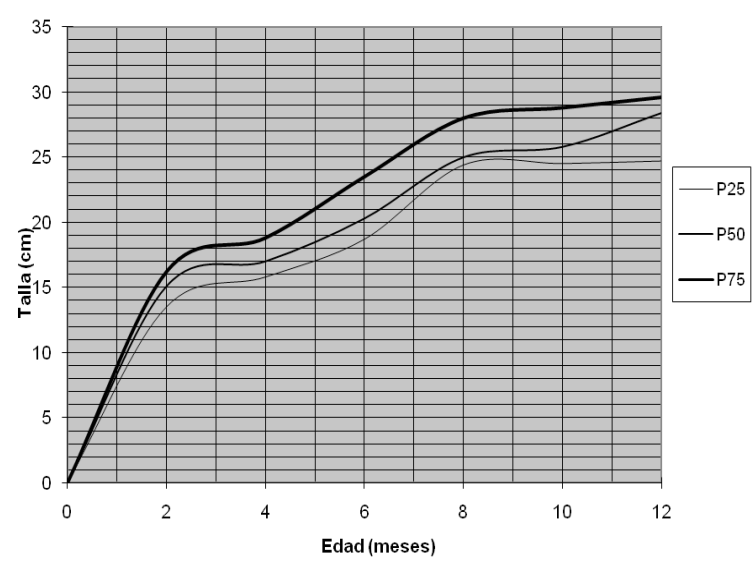

Figure 5. Curve of percentiles 25, 50, 75 of the size in centimeters of males from the Poodle breed 2 to 12 months old.

del ejemplar, el sexo y la actividad (11). Al observar los resultados obtenidos en este estudio encontramos que el color blanco del manto prima sobre los otros colores, entre los propietarios de los perros poodle en nuestro medio se tiene el concepto que el ejemplar de color blanco es más puro que el ejemplar de otro color, esto por falta de información sobre los estándares de la raza $(6,7)$.

En el estudio se encontraron varias malformaciones fenotípicas algunas de ellas penalizadas por las diferentes asociaciones y clubes caninos, uno de estos problemas, el criptorquidismo tiene un componente genético hereditario $(4,10)$; como norma preventiva estos ejemplares deberían ser esterilizados o no se les debería dejar reproducir.

También se observó la polidoncia en algunos ejemplares, cabe recordar que este problema va a 
In the study, phenotypical malformations were found, some of them penalized by different associations and canine clubs. One of these problems, cryptorchidism, has a hereditary genetic component $(4,10)$; as a preventive rule, these specimens should be sterilized or should not be able to reproduce.

Polydontia was also observed in some specimen. It is worth noting that this problem will cause adult animals to present bad formation of the oral cavity due to the overcrowding of teeth and the wrong location of some of the teeth that can cause bruising and pain when chewing $(3,12)$. All of this will result in halitosis, a periodontal disease, and the surgical corrections that should be performed to remove the supernumerary teeth $(12,13)$.

It is the duty of the veterinary to recommend early sterilization of females and males, because, as it was observed in the study, this practice is not widely used; emphasis should be made in all the benefits that are obtained when performing the procedure at an early age, such as the appearance of reproductive pathologies, unwanted pregnancy, suppression of the estrous cycle and low probability of appearance of breast tumors $(3,4)$.

Another significant finding of the study is with respect to the body condition reached at age one. Although a large percentage of these individuals reached adulthood with an ideal body condition of 3, these are not even $50 \%$ of the study's total. Therefore, it can be seen that there are serious problems in the nutrition of the puppies from this breed; since there is a high percentage of individuals that reached a body condition of less than 3 (low weight). This was observed primarily in females; however, there is a higher percentage of males that reached the body condition with over weight; it has been found that a puppy that arrives with a poor body condition score (less than 3) at the end of their growth cycle, it will result in an adult dog that will not perform well, will be susceptible to bacteria infection and parasites $(9,14)$.

Regarding weight, it was observed that the individuals reached an average weight between 3 and $5 \mathrm{~kg}$ at 12 months, something similar to Posada et al (2014) findings, although for them, it was the average size of smaller breeds (15).

When asking the owners about the nutrition of these animals, most responded that the nutrition was voluntary; owners do not know or do not use the food quantity tables from the labels found on animal food products. Some also responded that they gave pieces of their own food as treats for their dogs, because they believe that their dogs get tired of eating always the same thing. ocasionar que los animales adultos presenten mala conformación de la cavidad oral por el apiñamiento que se presentara en las piezas dentales y la mala ubicación de algunas de ellas que pueden ocasionar heridas y dolor a la masticación $(3,12)$, todo esto redundara en la presentación de halitosis, enfermedad periodontal y las correcciones quirúrgicas que se deban realizar para retirar las piezas dentales supernumerarias $(12,13)$

Es obligación del veterinario recomendar la esterilización temprana de la hembras y los machos, pues como se observó en el estudio esta práctica es poco utilizada; se debe hacer énfasis en todos los beneficios que se obtienen al realizar el procedimiento a temprana edad como son la presentación de patologías reproductivas, la preñez no deseada, la supresión del ciclo estral y la baja probabilidad de la presentación de tumores mamarios $(3,4)$.

Otro hallazgo significativo del estudio es en cuanto a la condición corporal con que llegaron al año de edad esto individuos, aunque el mayor porcentaje llegaron a la edad adulta con una condición corporal ideal de 3 estos no llegan hacer ni el 50\% del total del estudio, con esto se puede ver que hay serios problemas en la alimentación de los cachorros de esta raza; pues hay un alto porcentaje de individuos que llegaron con un condición corporal menor a 3 (bajo peso), esto se observó especialmente en la hembras; en cambio hay más porcentaje de machos que llegaron con sobre peso; se ha encontrado que un cachorro que llegue con una pobre calificación de condición corporal (menor de 3) al final de su crecimiento, redundara en un perro adulto que no se desempeñara bien en su trabajo, será susceptible a las infecciones bacterianas, parasitarias $(9,14)$.

En cuanto al peso se observó que los individuos alcanzaron un peso promedio de entre 3 y $5 \mathrm{~kg}$ a los 12 meses, algo parecido a lo encontrado por Posada et al (2014) aunque para ellos fue el peso promedio de las razas pequeñas (15).

Al indagar a los dueños de estos animales sobre la forma de alimentación la gran mayoría respondió que la alimentación era a voluntad, los propietarios no conocen o no utilizan las tablas de cantidad de alimento que traen impresos los empaques de los alimentos, también algunos respondieron que administraban trozos de su propia comida como golosinas a sus perros, pues piensan que sus perros se cansan de comer siempre los mismo.

También se encontró que lentamente procedimientos como la caudectomia empiezan a dejar de realizarse; en muchos eventos y exposiciones caninas ya no se penaliza los ejemplares con cola que anteriormente era 
It was also found that procedures such as caudectomy, have slowly stopped being performed; in many canine events and exhibitions, specimen with tail are no longer penalized; previously it was mandatory to amputate the tail so that the specimen would not be disqualified from the competitions $(6,7)$.

With respect to the elaboration of the growth curves, one must keep in mind that all growth curves or monitoring of weight have three parts; the first is an accelerated growth phase; the second is a slow growth stage and the third is the stabilization part (1).

These three stages were observed in the curves obtained with the data collected; in females it can be observed with respect to weight that the first phase of the curve ends approximately at 5-6 months, the second phase ends at 9-10 months and after, comes the stabilization phase; for size, the first phase ends at 3-4 months, the second phase at 8-9 months and after that, the third and last phase begin; in males, with respect to weight, the first phase ends at 4-5 months, the second at 9-10 months and after, the last phase; for size, the first phase ends at 2-3 months, the second at 7-8 months and after this, the stabilization phase begins.

The use of several percentiles to form the curves instead of only using one percentile has the purpose of monitoring in more detail each individual and it helps us locate and compare their growth or their weight with respect to the rest of the population in a given moment (1).

In conclusion, the veterinary must emphasize the recommendations for the puppies' nutrition during all phases of development $(9,15)$ and constantly monitor their fulfillment in order to perform the necessary corrections at a given moment, and must also discourage the reproductive practices that could cause phenotypical malformations in a specific breed.

The importance of having growth tables and curves like the ones obtained in this work is so they can be used as main tools for the evaluation and monitoring of the correct growth and development of puppies, as well as a point of reference to make the timely necessary nutritional corrections as in human medicine. obligatorio amputársela para no ser descalificados de las competencias $(6,7)$.

En cuanto a la construcción de las curvas de crecimiento hay que tener presente que toda curva de crecimiento o de seguimiento del peso consta de tres partes; la primera es una fase de crecimiento acelerado, la segunda es una etapa de crecimiento lento y la tercera parte es de estabilización (1).

En las curvas obtenidas con los datos recopilados, se observaron estas tres etapas; en las hembras se puede observar en cuanto al peso que la primera fase de la curva termina aproximadamente entre los 5-6 meses de edad, la segunda fase termina de 9-10 meses de edad y en adelante se presenta la fase de estabilización; para la talla, la primera fase termina de 3-4 meses de edad, la segunda de 8-9 meses y a partir de este tiempo comienza la tercera y última fase; en los machos en cuanto al peso la primera fase termina de 4-5 meses de edad, la segunda de 9-10 meses y en adelante la última fase, para la talla la primera fase termina de 2-3 meses de edad, la segunda de 7-8 meses después de este tiempo comienza la fase de estabilización.

La utilización de varios percentiles para formar las curvas en vez de una sola tiene como finalidad realizar un seguimiento más detallado de cada individuo y nos ayuda a ubicar y a comparar el crecimiento o el peso con el resto de la población en un momento dado (1).

En conclusión el veterinario debe hacer mucho énfasis con la recomendaciones para la alimentación de los cachorros durante todos el periodo de desarrollo $(9,15)$ y estar evaluando constantemente el cumplimiento de las mismas para poder en un momento dado realizar las correcciones necesarias, al mismo tiempo debe desalentar las practicas reproductivas que pueden generar mal formaciones fenotípicas en una raza especifica.

La importancia de tener tablas y curvas de crecimiento como las que se obtuvieron en este trabajo es puedan ser utilizadas como herramientas fundamentales para la evaluación y seguimiento de un correcto crecimiento y desarrollo de los cachorros, como también puede ser el punto de partida para realizar las correcciones nutricionales oportunas como se realiza en medicina humana. 


\section{REFERENCES}

1. Correa JA, Gómez JF, Posada R. Fundamentos de pediatría. Medellín: Presenco; 1994; 29-47.

2. Greco DS. Pediatric Nutrition. Vet Clin Small Anim; 2014; 44: 265-273.

3. Ettinger S. Feldman E. Tratado de medicina interna veterinaria, enfermedades del perro y el gato. Barcelona: ELSERVIER; 2007; 1400-1410.

4. Hoskins JD, Shelton GD. Pediatria veterinaria. $3^{\circ}$ ed. Philadelphia: Saunders; 2003; 55-61.

5. Palmer J. Perros y perritos. Madrid: LIBSA; 2001; 6-20.

6. Poodle breed standard. AKC [en línea] 2005 [fecha de acceso 17 de junio de 2015]; URL. Disponible en: http://www.akc.org/breeds/ poodle/.

7. Suarez R. Canicultura. $1^{\circ}$ ed. Madrid: Salvat; 1963; 131-135.

8. Bower J. El perro preguntas y respuestas. Madrid: LIBSA; 2000; 6-40.

9. Mark Morris Institute. Nutrición clínica en pequeños animales $4^{a}$ ed. Santafé de Bogotá: Inter-Médica S.A.I.C.I; 2000.
10. Birchard SJ, Sherding RG. Manual clínico de procedimientos en pequeñas especies. 2nd ed. Madrid: Mc Graw Hill; 2002.

11. National research council. Nutrient requirements of dogs and cats. 1a ed. Washington,D.C: National Academy Press 2006; 3-45.

12. Lewis JR. Therapeutic Decision Making and Planning in Veterinary Dentistry and Oral Surgery. Vet Clin Small Anim; 2013; 43: 471-487.

13. Gengler B. Exodontics Extraction of Teeth in the Dog and Cat. Vet Clin Small Anim; 2013; 43: 573-585

14. Pellegrino JF et al. Optimización del Rendimiento Deportivo en Caninos. Rev Inv Vet Perú 2014; 25(4): 449-454

15. Posada $\mathrm{S}$, et al. Application of the logistic model to describe the growth curve in dogs of different breeds. Rev. MVZ Córdoba 2014; 19(1):4015-4022 